\title{
Evaluation of Knowledge Gain among Participants from Mushroom Production Technologies Training Programmes
}

\author{
Harjot Singh Sohi*, P. S. Tanwar, Khushvir Singh and K. S. Matharu \\ Krishi Vigyan Kendra, Barnala, Guru Angad Dev Veterinary and Animal Sciences University, \\ Ludhiana-141004, India \\ *Corresponding author
}

\section{A B S T R A C T}

In the present study, a total 124 participants were judged for their knowledge gain after training on Mushroom Production Technologies. The training programme on

\section{Keywords}

Mushrooms, Button, Oyster, Spawn, Participants

Article Info

Accepted:

24 July 2020

Available Online:

10 August 2020 Mushroom Production technologies were arranged for rural youth, farmers and farm women of district Barnala, Punjab. Maximum knowledge gain (86.29 \%) was observed in Button mushroom compost production technologies followed by 81.45 per cent knowledge gain in learning about the commercial varieties of mushrooms popular in northern India. Whereas, lowest knowledge gain of $57.26 \%$ was observed in oyster mushroom cultivation technologies after the completion of the training programme. Before joining the training programme about 40.32 per cent of participants have knowledge of oyster mushroom production technologies followed by 33.87 per cent of participants with knowledge of suitable timing in seasonal mushroom cultivation. Participants were having lesser previous knowledge of 1.61 per cent of mushroom mycelium and spawn production. The satisfaction of the participants after the training programme indicates the importance of the vocational training programme on Mushroom Production Technologies arranged by Krishi Vigyan Kendra, Barnala.

\section{Introduction}

Mushroom productions have a major role to impart diversification in agriculture and it also helps in solving the issues related to quality food, health and environment. Use of direct/indirect agricultural, forestry, industrial and household wastes for commercial production of edible mushrooms helps to imparts income source and bio-convert it into a nutritious foods. With the continuous decrease in landholding per farmer, a mushroom cultivation could be a promising entrepreneur to meet the food shortages and to enhance the socio-economic status of the farmers. Mushroom farming adoption is continuous increasing and today it's is being practiced in more than 100 countries with its production rate increasing at 6-7\% annually. Present world production of mushrooms is around 34 million tons as per FAO Stat and in India mushroom cultivation is done on 198 
thousand hectare and production of 487 thousand metric tons (FAO, 2019).

In Punjab in year 2018-2019 mushroom production was 9424 metric ton (Anonymous, 2020). In India, Button mushroom is most popular variety both for domestic and export market purposes. In Punjab, India 175 medium scale seasonal cultivation of mushroom units has started and they targets nearby and big cities markets for their produce. However, during the winter season many rural areas rural youth farmers and farm women grows the seasonal button mushroom production particularly in Punjab, Haryana, Jammu and other northern states which targets to big cities like Delhi, Chandigarh, etc.

Time to time arrangements of vocational training programmes on Mushroom Production Technologies at Krishi Vigyan Kendra, Barnala has encouraged the rural youth, farmer and farm women to attain the knowledge for adoption it as a new entrepreneurship. Krishi Vigyan Kendra, Barnala and other farm science centers are in continuous help of the farm community and played an integral part to make the survival and strengthening of their enterprises. During the training programme basic principal of Krishi Vigyan Kendra was followed with a motto "Teaching by doing and learning by doing".

\section{Materials and Methods}

Present study was conducted with an aim to assess the knowledge gain of trainees. A total one hundred twenty four respondents were judged from six batches who were attended training programme on mushroom production technologies during 2016-2020. The participants of six different batches of Mushroom production technologies training programme were came from different blocks of district Barnala viz. Mehal Kalan, Barnala and Sehna at KVK (Krishi Vigyan Kendra), Barnala. During training programmes the participants were taught verbally in local languages and audio-visual aids were also used for better understanding of mushroom production technologies. Learning curiosity of new technologies, demand of time to start new enterprise or to get certificate are the basic requirement to participate in the training programme. Present data on the vocational training programme was calculated for knowledge gain by trainees.

The trainees were classified based on their socio-economic profile as illustrated in Table 1. Age group of the participants was categorized into three groups as: under 30 years age; between 31 to 40 year age and above 40 year. All participants were asked to give pre and post tests of the training programme to assess their gain in knowledge level. A questioner having a set of 15 questions in local language was used to assess the gain in knowledge level of participants. For each correct answer one mark and for incorrect zero marks was given. All the questions were of multiple choices based and maximum attainable score of an individual was fifteen marks.. The scores obtained from pre and post test were evaluated as per gain in knowledge level by the participants and it was calculated by the standard formula as per Ansari and Chandargi (2000).

Gain in knowledge $=\frac{\text { Post training score }- \text { Pre training score }}{\text { Pre training score }} \times 100$

\section{Results and Discussion}

Vocational training programme like Mushroom production technologies allows the unemployed/ employed rural youth, farmers and farm women to strengthen their skills and it opens a window to adopt new 
entrepreneurship. Vocational trainings would help in reducing any kind of weak links within the enterprises which rely heavily upon the others to attain basic work.

Krishi Vigyan Kendra, Barnala has organized vocational training programme on Mushroom production technologies viz. on Button mushroom (Agaricus bisporus); Oyster mushroom (Pleurotus ostreatus and Pleurotus spp.) and Shiitake mushroom (Lentinula edodes) in which the participated trainees to learn this technologies were classified on the basis of their socio-economic data which illustrated in Table 1. In present study data it has clearly shown that highest frequency of 47 participants from an age group of less than 30 years of age and has not significantly different from the number of participants taken part in mushroom production technologies from the age group of 31 to 40 and above. The enrollments of the participants were done irrespective to any category as the number of participants from general category was higher $(69.35 \%)$ followed by schedule caste $(18.54 \%)$ and other backward caste (12.09). These findings are in accordance with the study of Singh and Tanwar (2020). Education level of the participants were asked and it was reveled that 34.67 per cent of participants were studied up to senior secondary grade followed by 30.64 per cent participants studied up to matriculate level and 16.93 per cent of the participants were graduate and above degree holders. Only about 4.03 percent of the participants were illiterate or up to primary levels which were trained under mushroom production technologies. These findings are in same line with the study of Singh and Tanwar (2020). Higher number of the participants from the agricultural background which is 45.16 per cent followed by business man, unemployed, job personally and housewives $(17.74,16.83$, 6.45 and $6.45 \%$, respectively) which were enrolled under mushroom production training and similar findings were in concordance with Kaur (2016), Singh and Singh (2016) and Kumar et al., (2018). Majority of the participants about 36.29 per cent were having no agricultural land followed by small scale ( $<1 \mathrm{ha}$ ) land holders of 30.64 per cent as mushroom cultivation could help and efficient in utilization of small area of lands through vertical approach and can utilization of agricultural and industrial waste. Mushroom production can play a very significant role in alleviating the poverty and opportunity to generate employment among the unemployed youth (Rachna et al., 2013). About 58.06 per cent of the participants were from rural areas and 41.93 per cent from urban areas of district Barnala in consonance with the study of Singh and Tanwar (2020), Singh et al., (2010) and Singh and Singh (2016). In this training programmes majority of the participants were male which of 89.51 percent of the total candidates in consonance with the study of Singh and Tanwar (2018).

\section{Previous knowledge assessment}

The data from Table 2 illustrates the gain in knowledge by the participants before and after attaining the knowledge regarding the mushroom production technologies through the vocational trainings. From the pre and post test it was evaluated that the participants has maximum $(40.32 \%)$ knowledge of oyster mushroom cultivation and technologies just before the start of the training programme. Oyster mushroom is easiest to cultivate and economical, farmers generally cultivate this mushroom for their self consumption due to lack of proper marketing channels. Self preparation of mushroom spawn can reduce the cost of mushrooms cultivation, knowledge lead to spawn production was found minimum of 1.61 per cent just before the start of the training programme. 
Table.1 Socio-economic status of the respondents $(n=124)$

\begin{tabular}{|c|c|c|c|}
\hline Sr. No. & Particulars & Frequency (n*) & Percentage $(\%)$ \\
\hline 1. & $\begin{array}{l}\text { Age } \\
\text { Below } 30 \text { years } \\
\text { Between } 31 \text { to } 40 \text { years } \\
\text { and Above } 40 \text { years }\end{array}$ & $\begin{array}{l}47 \\
33 \\
44\end{array}$ & $\begin{array}{l}37.90 \\
26.61 \\
35.48\end{array}$ \\
\hline 2. & $\begin{array}{l}\text { Caste } \\
\text { General } \\
\text { Scheduled caste } \\
\text { Backward caste }\end{array}$ & $\begin{array}{l}86 \\
23 \\
15\end{array}$ & $\begin{array}{l}69.35 \\
18.54 \\
12.09\end{array}$ \\
\hline 3. & $\begin{array}{l}\text { Education } \\
\text { Illiterate } \\
\text { Primary } \\
\text { Middle level } \\
\text { Matriculate } \\
\text { Senior Secondary } \\
\text { Graduate }\end{array}$ & $\begin{array}{c}5 \\
5 \\
12 \\
38 \\
43 \\
21\end{array}$ & $\begin{array}{c}4.03 \\
4.03 \\
9.67 \\
30.64 \\
34.67 \\
16.93\end{array}$ \\
\hline 4. & $\begin{array}{l}\text { Occupation } \\
\text { Unemployed } \\
\text { Laborer } \\
\text { Agriculture } \\
\text { Business } \\
\text { Job } \\
\text { Housewife }\end{array}$ & $\begin{array}{c}21 \\
9 \\
56 \\
22 \\
8 \\
8\end{array}$ & $\begin{array}{c}16.83 \\
7.25 \\
45.16 \\
17.74 \\
6.45 \\
6.45\end{array}$ \\
\hline 5. & $\begin{array}{l}\text { Agricultural Landholdings } \\
\text { Landless } \\
\text { Marginal (<1 ha) } \\
\text { Small (1-2 ha) } \\
\text { Large (>2 ha) }\end{array}$ & $\begin{array}{l}45 \\
38 \\
22 \\
19\end{array}$ & $\begin{array}{l}36.29 \\
30.64 \\
17.74 \\
15.32\end{array}$ \\
\hline 6. & $\begin{array}{l}\text { Gender } \\
\text { Male } \\
\text { Female }\end{array}$ & $\begin{array}{c}111 \\
13\end{array}$ & $\begin{array}{l}89.51 \\
10.48\end{array}$ \\
\hline 7. & $\begin{array}{l}\text { Resident } \\
\text { Rural } \\
\text { Urban }\end{array}$ & $\begin{array}{l}72 \\
52\end{array}$ & $\begin{array}{l}58.06 \\
41.93\end{array}$ \\
\hline
\end{tabular}


Table.2 Knowledge gain of the participants through mushroom production technologies

\begin{tabular}{|c|c|c|c|c|}
\hline $\begin{array}{l}\text { Sr. } \\
\text { No. }\end{array}$ & Parameter & $\begin{array}{l}\text { Pre-test } \\
\text { evaluation } \\
(\%)\end{array}$ & $\begin{array}{l}\text { Post-test } \\
\text { evaluation } \\
\quad(\%)\end{array}$ & $\begin{array}{l}\text { Gain in } \\
\text { knowledge }\end{array}$ \\
\hline 1. & $\begin{array}{l}\text { World scenario of marketing and } \\
\text { mushroom industries }\end{array}$ & 7.25 & 79.03 & 71.78 \\
\hline 2. & $\begin{array}{l}\text { Commercial varieties of mushrooms } \\
\text { which are popular in Northern India }\end{array}$ & 14.51 & 95.96 & 81.45 \\
\hline 3. & $\begin{array}{l}\text { Suitable timing for the seasonal cultivation } \\
\text { of mushrooms }\end{array}$ & 33.87 & 96.77 & 62.90 \\
\hline 4. & $\begin{array}{l}\text { Medicinal values of the different } \\
\text { mushrooms }\end{array}$ & 4.03 & 64.51 & 60.48 \\
\hline 5. & $\begin{array}{l}\text { How to prepare Button mushroom } \\
\text { compost through long, short and indoor } \\
\text { methods. }\end{array}$ & 12.09 & 98.38 & 86.29 \\
\hline 6. & $\begin{array}{l}\text { How to prepare Bamboo based sheds for } \\
\text { seasonal cultivation }\end{array}$ & 37.90 & 98.38 & 60.48 \\
\hline 7. & $\begin{array}{l}\text { How to prepare casing material for Button } \\
\text { mushroom }\end{array}$ & 14.51 & 84.67 & 70.16 \\
\hline 8. & $\begin{array}{l}\text { How to harvest a Button, oyster and } \\
\text { shiitake Mushroom }\end{array}$ & 31.45 & 96.77 & 65.32 \\
\hline 9. & Oyster mushroom cultivation technologies & 40.32 & 97.58 & 57.26 \\
\hline 10. & $\begin{array}{l}\text { Drying procedure for oyster and shiitake } \\
\text { mushrooms }\end{array}$ & 4.83 & 79.83 & 75.00 \\
\hline 11. & $\begin{array}{lll}\text { Shiitake } & \text { mushroom } & \text { production } \\
\text { technologies } & & \end{array}$ & 6.45 & 66.12 & 59.67 \\
\hline 12 & $\begin{array}{l}\text { Mushroom mycelium and spawn } \\
\text { production technologies }\end{array}$ & 1.61 & 62.90 & 61.29 \\
\hline 13 & $\begin{array}{l}\text { Processing and value addition of } \\
\text { mushrooms }\end{array}$ & 12.09 & 70.16 & 58.07 \\
\hline 14 & Packaging and marketing of mushrooms & 25.80 & 83.87 & 58.07 \\
\hline 15 & $\begin{array}{l}\text { Insect-pest and disease management of } \\
\text { mushrooms }\end{array}$ & 17.74 & 79.03 & 61.29 \\
\hline
\end{tabular}

After the vocational training the rural youth, farmers and farm women has improved in gain in their knowledge level on mushroom production technologies. On studying the different parameters related to popular commercial varieties of mushroom; suitable time for seasonal cultivation of mushrooms; preparation of Button mushroom compost technologies; preparation of seasonal bamboo based structures; harvesting methodology of mushrooms and oyster mushroom cultivation the participants had scored above 95 per cent in their post test evaluation which was taken after the completion of the training programme similar results were observed by Kumar et al., (2018).

By comparing pre and post tests on vocational training program it was observed that maximum $86.29 \%$ of knowledge gain in 
preparation of Button mushroom compost followed by $81.45 \%$ knowledge gain in learning the commercial varieties of mushrooms that popular in Northern India. Similar results were also reported by (Kumar et al., 2018). However least knowledge gain of $57.26 \%$ was observed in the oyster mushroom cultivation technologies might be due to prior higher knowledge (40.32 \%) before the training programme among the participants. The gain in knowledge level knowledge in ascending order $(58.07,58.07$, $59.67,60.48,61.29$ and $61.29 \%$ ) in the processing and value addition of mushroom, packaging and marketing of mushroom, shitake mushroom production technologies, seasonal shed preparation, mushroom mycelium and spawn production and insectpest/disease management in mushroom production, respectively. Similar type of findings for gain in knowledge about harvesting of mushrooms, disease management and value addition of mushrooms was in same line with Kumar et al., (2018).

In conclusion, vocational training programmes oriented with the help of Krishi Vigyan Kendra, Barnala was found effective in gain in knowledge level of the rural youth, farmers and farm women in the field of mushroom production technologies. Such types of training programme besides increasing the knowledge level it also motivates the participants to take risks to increase their socio-economic status by adopting new entrepreneurships.

\section{References}

Anonymous, 2020. State department of Horticulture. Govt. of Punjab. https://punjabhorticulture.com/Docume nts/Crops/Mushroom/Mushroom_201819.pdf.

Ansari, M. R. and Chandargi, D. M. 2000.
Effectiveness of induction training programme organized for Assistant Agricultural Officers (Farm women). Journal of Extension Education, 11 (1): 2645-2650.

FAO, 2019. 'The state of food and agriculture'. Available at: http://www.fao.org/faostat/en/\#data/QC.

Kaur, K. 2016. Impact of training course on knowledge gain of mushroom trainees. Journal of Krishi Vigyan, 4 (2): 54-57.

Kumar, P., Bharty, S., Singh, R. K., Kumar, K. and Rani, N. 2018. Impact of oyster mushroom (Pleurotus ostreatus) training on socio- economic and knowledge of tribal woman of Hazaribag, Jharkhand, India. International Journal of Current Microbiology and Applied Sciences, 7: 1106-1111.

Kumar, P., Bharty, S., Singh, R. K., Kumar, K. and Rani, N. 2018. Impact of Oyster Mushroom (Pleurotus ostreatus) Training on Socio- Economic and Knowledge of Tribal Woman of Hazaribag, Jharkhand, India. International Journal of Current Microbiology and Applied Sciences, 7: 1106-1111.

Pandey, A., Gupta, N., Pandey, A., Singh, S. 2017. Impact of vocational training on value addition in knowledge and adoption of rural women. International Journal of Pure and Applied Bioscience, 5 (1): 129-134.

Rachna, Goel, R. and Sodhi, G. P. S. 2013. Evaluation of vocational training programmes organized on mushroom farming by Krishi Vigyan Kendra Patiala. Journal of Krishi Vigyan, 2(1): 26-29.

Singh, D. and Singh, K. B. 2016. Evaluation of vocational training programmes on mushroom cultivation. Indian Journal of Economics and Development, 12 (2): 387-392. 
Singh, K. and Tanwar, P. S. 2018. Impact analysis of vocational training programmes on knowledge gain of ornamental fish culture trainees. International Journal of Pure and Applied Bioscience, 6 (3): 509-512.

Singh, K. and Tanwar, P. S. 2020. Impact of integrated fish farming vocational trainings on knowledge gain by trainees. Journal of Entomology and Zoology
Studies, 8 (3): 510-513.

Singh, K., Pashin, R. and Saini, S. K. 2010. Evaluation of the agricultural vocational training programmes conducted by the Krishi Vigyan Kendras (Farm Science Centres) in Indian Punjab. Journal of Agriculture and Rural Development in the tropics and Subtropics, 111 (2): 6577.

\section{How to cite this article:}

Harjot Singh Sohi, P. S. Tanwar, Khushvir Singh and Matharu, K. S. 2020. Evaluation of Knowledge Gain among Participants from Mushroom Production Technologies Training Programmes. Int.J.Curr.Microbiol.App.Sci. 9(08): 3297-3303.

doi: https://doi.org/10.20546/ijcmas.2020.908.377 